DOI: https://doi.org/10.47405/mjssh.v6i10.1143

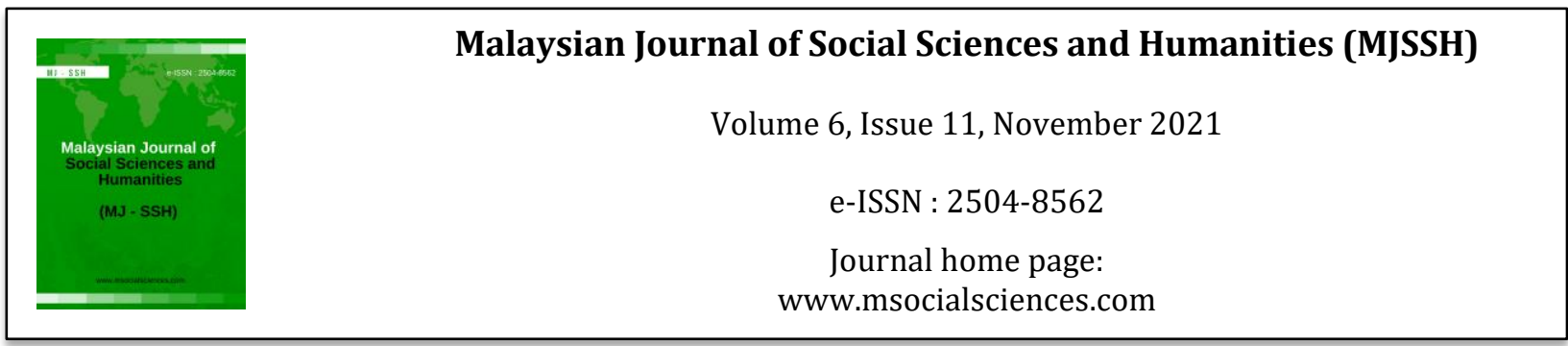

\title{
Perubahan Tradisi Penempatan Masyarakat Melayu Brunei di Kawasan Pantai Barat Borneo Utara: Impak Terhadap Sosioekonomi (1881-1941)
}

\author{
Dg. Junaidah Binti Awang Jambol ${ }^{1}$, Baszley Bee Bin Basrah Bee ${ }^{1}$ \\ 1Fakulti Sains Sosial dan Kemanusiaan, Universiti Malaysia Sabah (UMS), \\ Jalan UMS, 88400 Kota Kinabalu, Sabah, Malaysia
}

Correspondence: Dg. Junaidah Binti Awang Jambol (dgjunaidah@ums.edu.my)

\begin{abstract}
Abstrak
$\overline{\text { Makalah ini adalah berkaitan dengan perubahan tradisi penempatan masyarakat Melayu Brunei di }}$ kawasan pantai barat Borneo Utara (1881-1941) dan impaknya terhadap sosioekonomi masyarakat ini semasa zaman pentadbiran British North Borneo (Charted) Company (BNBC). Tujuan utama makalah ini ialah untuk menjelaskan perubahan serta pengekalan penempatan masyarakat ini selepas tamatnya pemerintahan Kesultanan Brunei. Pengambilalihan BNBC terhadap Borneo Utara menyebabkan wujudnya pemisahan pemerintahan di antara masyarakat Melayu Brunei di Borneo Utara dengan masyarakat Melayu di negara Brunei Darussalam dalam aspek sosial dan ekonomi. Perubahan dan pengekalan penempatan inilah yang akan cuba dibahaskan dalam penulisan ini adalah bagi memahami ajukan masyarakat Melayu Brunei wujud sebagai sebuah entiti masyarakat yang berbeza daripada masyarakat Melayu yang berada di negara Brunei Darussalam.
\end{abstract}

Kata kunci: penempatan, Melayu Brunei, impak, sosioekonomi

\section{The Changes of the Tradition of the Brunei Malay Community's Settlements in the West Coast of North Borneo: Impact on the Socioeconomic (1881-1941)}

\begin{abstract}
This paper is related to the changes in the tradition of the Brunei Malay settlements in the West Coast of North Borneo (1881-1941) and its impact on their socio-economy during the administration of the British North Borneo (Chartered) Company (BNBC) after the end of the rule of the Brunei Sultanate. BNBC's acquisition over North Borneo led to a separation between the Brunei Malay community in North Borneo with the Brunei Malay community in Brunei Darussalam in terms of society and economy. Alteration and preservation of these settlements will be discussed in this paper to understand the difference of both Brunei Malay communities exists as a public entity distinct from the parent community residing in Brunei Darussalam.
\end{abstract}

Keywords: settlement, Brunei Malay, impact, socioeconomic 


\section{Pengenalan}

Kedatangan masyarakat Melayu Brunei ke kawasan pantai barat utara Borneo sering kali menjadi persoalan ramai pihak terutamanya para pengkaji sejarah Brunei. Persoalan utama yang sering diajukan ialah adakah masyarakat Melayu Brunei yang wujud di kawasan pantai barat kini adalah masyarakat yang sememangnya berasal dari lingkungan kawasan Tanah Kerajaan Brunei ataupun hanyalah masyarakat yang tinggal di kawasan Sungai Kuripan dan Sungai Tulin yang telah membentuk sistem politik, ekonomi dan sosial sendiri serta beranggapan bahawa mereka adalah sebahagian daripada induk masyarakat Melayu Brunei. Berdasarkan kepada persoalan tadi, didapati bahawa sebelum tahun 1881 lagi, kebanyakan kawasan yang diduduki oleh masyarakat Melayu Brunei di kawasan pantai barat merupakan kawasan yang pernah dikuasai oleh Kesultanan Brunei. Malahan British dan BNBC tidak pernah mengetepikan penguasaan Kesultanan Brunei terhadap kawasan tersebut memandangkan tidak wujud sempadan yang memisahkan antara masyarakat Melayu Brunei di utara Borneo dengan masyarakat Melayu Brunei di negara Brunei Darussalam. Dalam konteks ini, keunikan sejarah pemerintahan Kesultanan Brunei dapat dilihat melalui pengekalan sistem monarkinya lebih daripada sepuluh abad yang lalu dengan genealogi dinastinya yang tidak pernah terputus. Perlu difahami bahawa kemunculan Kesultanan Brunei sebagai kuasa yang kuat di Kepulauan Nusantara bermula apabila para sultannya telah berjaya membangunkan dan memantapkan kekuatan ketenteraan dan pertahanannya dari serangan beberapa kerajaan jiran dan kumpulan masyarakat pelanun. Malah Kesultanan Brunei telah menakluki atau berpengaruh ke atas keseluruhan kawasan Pulau Borneo meliputi Sambas, Yotawaringin, Pontianak, Coti, Pasir, Barau, Tawi-Tawi, Banjar, Bolongan, Balabak, Banggi, Balambangan, Matananai dan Palawan (Caroll, 1986: 1-2; Mohd. Jamil Al-Sufri, 2002: 35; Zaini, 1983: 2).

Pada tahun 1871, wilayah jajahan atau Kuripan dan Tulin utama bagi Kesultanan Brunei di utara Borneo dapat dibahagikan kepada 20 kawasan iaitu Putatan, Membakut, Tuaran, Mengkabong, Menggatal, Inanam, Api-Api, Sembulan, Nafas Tambalang, Kinarut, Pengalat Besar, Papar, Gaya, Pengalat Kecil, Padas-Klias, Bongawan, Benoni, Kimanis, Padas-Damit dan Kawang (Ranjit, 2003: 306). Pada tahun 1888 telah berlaku pemisahan antara kelompok masyarakat Melayu Brunei di utara Borneo dengan masyarakat Melayu Brunei di kawasan Tanah Kerajaan Kesultanan Brunei. Pemisahan ini berlaku selepas termeterainya perjanjian perlindungan British iaitu Protectorate Agreemeent ${ }^{i}$ yang menyaksikan berlakunya pemajakan utara Borneo kepada pihak BNBC. Kesan perjanjian tersebut juga secara tidak langsung telah menyebabkan kekuasaan Sultan Brunei semakin berkurangan (Ranjit, 1984: 6).

\section{Penempatan Tradisional Masyarakat Melayu Brunei}

Tradisinya, masyarakat Melayu Brunei di kawasan pantai barat utara Borneo sememangnya mendirikan penempatan berdekatan dengan persisiran pantai dan sungai yang dibawa bersama dari tempat asal mereka. Kebanyakan mereka ini telah pun menetap di darat berhampiran dengan sungai sebelum tahun 1881 lagi. Majoriti masyarakat Melayu Brunei yang tinggal di pesisiran pantai dan sungai yang menjalankan aktiviti berkaitan maritim seperti menangkap ikan dan membuat perahu. Walau bagaimanapun, kegiatan ini hanyalah dalam bentuk sara diri sahaja, sekiranya pendapatan mereka berlebihan barulah hasil-hasil tangkapan tersebut akan dikeringkan dan ditukar dengan masyarakat lain. Bagi golongan bangsawan Brunei pula kegiatan ekonomi mereka lebih tertumpu kepada aktiviti perdagangan yang memberikan keuntungan yang lebih banyak.

Kebanyakan masyarakat Melayu Brunei yang datang ke kawasan pantai barat terdiri daripada golongan pembesar (Pengiran dan Ampuan) pengawal, ulun (hamba) dan rakyat biasa. Mereka membuka kawasan penempatan baru yang biasanya terletak di pesisiran pantai ataupun berhampiran dengan sungai bagi memudahkan mereka menjalankan aktiviti perdagangan dan mendapatkan bekalan makanan serta minuman. Menurut informan lagi, mereka belayar ke kawasan pantai barat melalui pesisir Teluk Brunei dan Teluk Kimanis dengan menggunakan Belarai, Gubang dan Jumpong. ${ }^{\text {ii }}$ Lazimnya, masyarakat Melayu Brunei yang datang ke kawasan Papar, mereka akan berhenti terlebih dahulu di Pulau Labuan dan selepas itu singgah di Pulau Kalampunian dan Pulau Tiga. Bagi menentukan arah dan kedudukan 
Papar, mereka akan menjadikan Bukit Kinandukkan yang terletak di Kuala Sungai Papar dan Pulau Layang-Layang sebagai petunjuk (Haji Ampuan Mumin, 2010). ${ }^{\text {iii }}$

Perlu difahami juga bahawa masyarakat Melayu Brunei yang berhijrah ke kawasan pantai barat terdiri daripada golongan bertaras ${ }^{\text {iv }}$ dan berbalat. ${ }^{v}$ Kebanyakan mereka ini berhijrah disebabkan oleh faktor dalaman istana di samping didorongi oleh faktor keselamatan dan ekonomi yang terdapat di utara Borneo. ${ }^{\text {vi }}$ Umpamanya, penempatan pertama masyarakat Melayu Brunei di Benoni dibuka oleh keturunan Sultan Abdul Kahar yang telah membina penempatan di persisiran Sungai Benoni sehinggalah ke Bukit Pungit yang terletak di batu 32 Membakut. Peristiwa pembukaan Benoni ini bermula apabila Sultan Mahyuddin memberontak dan memburu semua pengikut Sultan Hakkul Mubin, maka mereka terpaksa memerangi masyarakat Dusun untuk merebut kawasan Benoni bagi membolehkan mereka bersembunyi di kawasan daratan. Pada ketika itu, Benoni telah dijadikan sebagai tempat persembunyian keturunan Hakkul Mubin dan para pengikutnya. Kebanyakan mereka ini juga telah menukarkan gelaran mereka kepada Ampuan. Golongan Pengiran mula datang ke Benoni apabila Pengiran Muluk atau Pengiran Anak Damit ${ }^{\text {vii }}$ membawa lari anak dan sepupu-sepupunya ke Benoni untuk disembunyikan. Peristiwa ini bermula apabila Pengiran Pemancha telah dibunuh manakala isteri Pengiran Anak Damit juga turut terbunuh. Pengiran Anak Damit telah membawa lari tiga orang anaknya iaitu Pengiran Besar, Pengiran Buntar dan Pengiran Abbas serta isteri dan anak Pengiran Pemancha ke Benoni. Rentetan daripada peristiwa pembunuhan tersebut, kebanyakan kaum kerabat istana telah menjadikan Benoni sebagai tempat persembunyian dan tidak kurang juga kaum kerabat yang meninggalkan istana Brunei kerana disingkirkan dan tidak berpuas hati dengan pemerintahan Sultan Brunei. Kedatangan golongan Pengiran ke Benoni telah menyebabkan berlakunya perkahwinan di antara golongan Ampuan dan Pengiran bertaras yang akhirnya membawa kepada kelahiran generasi tulen Ampuan dan Pengiran bertaras. Hal ini terbukti apabila dulunya masyarakat Melayu Brunei di Benoni tidak dibenarkan untuk berkahwin campur dengan kaum lain bagi memastikan ketulenan status gelarannya sentiasa terpelihara (Pengiran Abdul Rahman, 2016).

Kewujudan sebuah Kota Lama yang dimiliki oleh Sultan Hakkul Mubin di Bukit Kinarut pada tahun 1865 merupakan bukti kepada kehadiran masyarakat Melayu Brunei ke kawasan pantai barat. Walau bagaimanapun, meskipun Kinarut pernah mencatatkan sejarah sebagai tempat pelarian masyarakat Melayu Brunei, Kinarut pada masa kini bukanlah kawasan penempatan yang didominasi oleh masyarakat Melayu Brunei. Hal ini mungkin berlaku disebabkan oleh keadaan geografinya yang tidak sesuai untuk dijadikan sebagai kawasan penempatan bagi masyarakat Melayu Brunei kerana keadaannya yang berbukit-bukau. Lazimnya, masyarakat Melayu Brunei lebih suka untuk tinggal di kawasan persisiran sungai kerana memudahkan mereka untuk menjalankan aktiviti perdagangan, perikanan dan berulang-alik ke Brunei. Oleh itu, tidak hairanlah sekiranya kebanyakan daripada mereka memilih untuk menetap di kawasan-kawasan pesisiran sungai, laut dan tanah datar berbanding dengan kawasan berbukit-bukau seperti Kinarut. Namun begitu, Kinarut bolehlah dikatakan sebagai 'landmark' yang menunjukkan kedatangan masyarakat Melayu Brunei ke beberapa daerah di kawasan pantai barat (Osman, 1996: 83).

Selain itu, penempatan masyarakat Melayu Brunei di kawasan pantai barat ini juga sebenarnya terbentuk hasil daripada aktiviti kelautan yang dijalankan oleh masyarakat Melayu Brunei semenjak zaman pemerintahan Sultan Bolkiah lagi. Hal ini kerana masyarakatnya bukan sahaja mahir dalam ilmu pelayaran dan pembuatan perahu tetapi juga mempunyai pengetahuan yang luas dalam aktiviti-aktiviti kelautan. Kemahiran-kemahiran inilah secara tidak langsung telah mendorong mereka untuk meneroka kawasan-kawasan baru. Pada awalnya, masyarakat ini datang ke kawasan Pantai Barat untuk mengembara dan berdagang dengan menggunakan belarai (kapal layar) dan bergerak dalam kumpulankumpulan kecil. Mereka kemudiannya telah bertindak membina penempatan di persisiran sungai dan laut untuk memudahkan mereka singgah berehat dan mendapatkan bekalan. Lama-kelamaan penempatan ini kemudiannya telah berkembang menjadi sebuah perkampungan masyarakat Melayu Brunei lewat abad ke-18. ${ }^{\text {vii }}$ Hal ini dapat dibuktikan apabila sehingga kini masih lagi terdapat segelintir masyarakat Melayu Brunei yang menetap di sepanjang pesisiran pantai dan muara sungai Papar, Bongawan, Kimanis dan Membakut yang suatu ketika dahulu pernah mencatat sejarah menjadi tempat persinggahan para pedagang Brunei. Kedudukan geografi yang unik dan strategik ini secara tidak 
langsung telah menjadikan masyarakat Melayu Brunei sebagai masyarakat yang dominan di kawasan Pantai Barat.

\section{Perubahan Penempatan Masyarakat Melayu Brunei}

Pentadbiran BNBC di Borneo Utara bermula pada tahun 1881 telah merubah ruang penempatan masyarakat Melayu Brunei ekoran daripada dasar ekonomi yang diperkenalkan terhadap penduduk peribumi di Borneo Utara. Sebelum pentadbiran BNBC, masyarakat Melayu Brunei menjalankan aktiviti perdagangan secara bebas tanpa wujud sebarang sekatan daripada para pembesar Brunei. Namun begitu, selepas munculnya pentadbiran BNBC, masyarakat Melayu Brunei menghadapi masalah persaingan daripada pedagang British dan Cina sehingga menyebabkan para pedagang Melayu Brunei tidak berupaya untuk menyaingi perdagangan pihak imigran asing. Kesannya, penglibatan para pedagang Melayu Brunei dalam kegiatan perdagangan semakin berkurangan. Ekoran daripada itu, kebanyakan masyarakat Melayu Brunei mula menjalankan kegiatan sampingan seperti bertani, memungut hasil hutan, menganyam tikar, membuat kraf tangan dan sebagainya bagi memenuhi keperluan keluarga mereka. Meskipun pada awalnya kegiatan sampingan ini hanya dijalankan apabila berlakunya musim tengkujuh yang menghalang mereka untuk turun ke laut namun, selepas pihak BNBC memperkenalkan dasar dan Undang-Undang Tanah untuk menggalakkan penempatan, penanaman padi dan buah-buahan dalam kalangan penduduk, maka masyarakat Melayu Brunei mulai mengubah sepenuhnya kegiatan ekonomi mereka kepada sektor pertanian (Whelan, 1968: 150; Wong, 2012: 426; Marilyn et al., 2015: 85).

Dasar Pentadbiran BNBC yang tidak memberikan tumpuan terhadap ekonomi sara diri telah menyebabkan masyarakat Melayu Brunei tertinggal dari segi peningkatan sumber pendapatan. Contohnya, para nelayan Melayu Brunei yang tidak diberikan perhatian telah mendorong mereka untuk terlibat dalam kegiatan perladangan estet getah yang diperkenalkan oleh pihak BNBC. Apabila masyarakat Melayu Brunei mula terlibat dalam kegiatan perladangan, mereka mula berpindah ke lokasi penempatan jauh dari sungai dan beranjak ke bahagian hilir sungai bagi memudahkan mereka terlibat dalam sektor ekonomi ini. Kehadiran masyarakat Melayu Brunei dan kaum lain di kawasan tersebut juga telah menyebabkan masyarakat Dusun dan Murut berpindah ke kawasan pedalaman untuk membuka tanah baru. Meskipun demikian perkara yang sama berlaku sebelum ini iaitu perpindahan penempatan masyarakat Dusun dan Murut ke bahagian hulu sungai manakala masyarakat Melayu Brunei pula mengambil alih bahagian tanah datar berhampiran dengan sungai berlaku melalui proses pertukaran barang antara dua masyarakat tersebut dengan masyarakat Melayu Brunei; tanah mereka ditukarkan dengan gong tembaga yang pada masa itu sangat berharga kepada masyarakat Dusun dan Murut. Selain itu, mereka juga tidak berminat untuk tinggal bersama dengan masyarakat Melayu Brunei kerana perbezaan agama, budaya dan bahasa. Melalui pertukaran tersebut, masyarakat Dusun dan Murut beranjak jauh ke pedalaman dan membuka penempatan baru di situ (Ampuan Mumin, 2010).

Selain melalui pertukaran barang, sebahagian kelompok masyarakat Melayu Brunei juga menggunakan kekerasan untuk mendapatkan tanah yang dimiliki oleh masyarakat Dusun dan Murut (Aampuan Mumin, 2010). Kawasan Kampung Benoni dan Bongawan yang terletak di kawasan Papar merupakan contoh kawasan yang telah dirampas dan diambil alih oleh masyarakat Melayu Brunei secara paksa daripada kaum Dusun. Penduduk asal Benoni telah diusir keluar dari kawasan berkenaan setelah tewas dalam pertarungan untuk mendapatkan kawasan tersebut. Kawasan yang ditinggalkan oleh masyarakat Dusun ini sememangnya sesuai untuk aktiviti pertanian (Pengiran Ahmad Fauzi, 2011).

\section{Impak Ekonomi}

Penglibatan pihak BNBC dalam aktiviti perdagangan telah memberikan saingan hebat kepada para pedagang Melayu Brunei sama ada dari segi saiz kapal yang lebih besar ${ }^{\mathrm{ix}}$ dan modal yang sangat banyak. Kelebihan ini telah menyebabkan para pedagang Melayu Brunei tidak berupaya untuk menyaingi pihak BNBC dan implikasinya, kegiatan para pedagang kecil Melayu Brunei semakin terhad di sungai-sungai tertentu sahaja yang lebih bercorak sara diri (British North Borneo Herald, July 1 
1883:2). Perkara ini menyebabkan aktiviti perdagangan masyarakat Melayu Brunei semakin merosot di Teluk Kimanis, maka ramai masyarakat Melayu Brunei yang menetap di Kimanis telah dibawa berhijrah oleh pihak BNBC ke bahagian Kota Marudu dan Kudat untuk bekerja di estet getah dan seterusnya membuka penempatan di situ. Contohnya adalah seperti keluarga Tuan Haji Tahir yang berasal dari Kimanis dan keluarga Pengiran Ibrahim Bin Pengiran Arshad yang berasal dari Tuaran. Mereka telah dibawa berhijrah oleh pihak BNBC dengan menggunakan kapal besar ke bahagian pantai barat utara iaitu Kota Marudu dan Kudat (Mohd. Azman, 2011).

Di dalam aspek pertanian pula, didapati bahawa masyarakat Melayu Brunei mula terlibat secara aktif dalam aktiviti penanaman padi apabila munculnya pihak BNBC mentadbir kawasan pantai barat Borneo Utara. Masyarakat Melayu Brunei di kawasan Papar umpamanya, mula terlibat dalam aktiviti penanaman padi apabila Awang Dusi dilantik oleh pihak BNBC mentadbir kawasan tersebut. Sebelumnya, masyarakat Melayu Brunei menjalankan aktiviti pertanian sebagai aktiviti sampingan sahaja. Pada ketika itu, penanaman padi diusahakan secara meluas oleh masyarakat Melayu Brunei yang menetap di Kampung Benoni (Pengiran Ahmad Fauzi, 2011). Di Bongawan pula sebilangan besar penduduknya juga mengusahakan tanaman padi terutamanya di Kampung Laut, Kampung Tengah, Kampung Tarap, Kampung Giok, Kampung Darat Pauh, Kampung Serbang dan Kampung Biau. Kesemua kawasan ini pada asalnya diduduki oleh masyarakat Dusun sebelum diambil alih oleh masyarakat Melayu Brunei (Pengiran Yassin, 2010). Kegiatan penanaman padi ini telah dikomersialkan oleh BNBC berikutan masalah kekurangan beras di Borneo Utara. Papar, Putatan dan Penampang pada ketika itu muncul sebagai pengeksport utama padi, susu getah, jelutung dan kelapa. Pada tahun 1878 sehinggalah tahun 1894, BNBC telah mengimport beras untuk memenuhi keperluan makanan. Ekoran daripada itu, banyak kawasan baru di sekitar Pantai Barat telah dibuka untuk menanam padi. Pada tahun 1939, BNBC telah memperalatkan pengaruh KAN untuk mengambil tanah-tanah yang dimiliki oleh masyarakat peribumi. Kegiatan pengambilan tanah daripada penduduk peribumi untuk aktiviti penanaman padi telah berjaya menaikkan hasil keluaran padi di Borneo Utara (Ranjit, 2003: 62-63; Osman, 1996: 138-139; Tregonning, 2007: 94-95).

Selain itu, pengenalan pertanian ladang di kawasan pantai barat oleh pihak BNBC juga telah menyebabkan wujudnya penempatan masyarakat Melayu Brunei di sepanjang landasan keretapi dari Jesselton sehinggalah ke Beaufort. Kebanyakan daripada masyarakat Melayu Brunei ini bekerja di ladang getah sebagai penoreh getah, pengangkut susu getah, pencabut rumput dan penebang pokok. Berdasarkan kenyataan informan Ampuan Mumin Bin Ampuan Tuah, beliau sendiri pernah bekerja sebagai penoreh getah dan penebas pokok di Lumat Estate semasa pemerintahan BNBC. Menurut beliau lagi, tidak semua masyarakat Melayu Brunei ini bekerja di ladang getah. Hal ini kerana kegiatan ini hanya melibatkan masyarakat Melayu Brunei yang tinggal berhampiran dengan kawasan ladang getah sahaja seperti di kawasan Benoni, Membakut, Kimanis, Bongawan, Kinarut, Putatan dan lain-lain lagi. ${ }^{x}$ Walau bagaimanapun, apabila tiba musim menanam dan menuai padi, mereka akan meninggalkan kerjakerja di ladang getah. Pada ketika itu, padi yang ditanam mengambil masa 6 bulan untuk dituai dan 6 bulan lagi digunakan oleh masyarakat Melayu Brunei untuk bekerja di ladang getah (Ampuan Mumin, 2010).

Pentadbiran BNBC juga telah menyebabkan masyarakat Melayu Brunei tidak lagi terikat dengan ekonomi tradisional kerana terlibat dengan ekonomi komersial yang diperkenalkan oleh BNBC. Hal ini terbukti apabila pihak BNBC menggunakan masyarakat Melayu Brunei sebagai tenaga buruh untuk aktiviti pembalakan. Dalam sektor ini mereka menjadi pekerja Syarikat E.E Abrahamson \& Co yang merupakan syarikat pembalakan di Borneo Utara. Menurut informan Hj Tajuddin Bin $\mathrm{Hj}$ Matussin, pekerja-pekerja yang berada di bawah syarikat ini dikenali sebagai "Pesagi" xi mereka akan bekerja dalam satu kumpulan yang dianggotai 10 hingga 20 orang. Masa bekerja tidak tetap dan bergantung kepada permintaan pihak syarikat. Biasanya mereka akan menebang pokok balak semasa musim kemarau dan membawanya ke tepi sungai dengan menggunakan kerbau. Kayu Balak tersebut akan dihanyutkan semasa musim tengkujuh, sewaktu kuantiti air sungai meningkat dan semakin deras. Setelah kerja mereka selesai dalam tempoh dua hingga tiga bulan maka mereka akan dibayar upah yang kemudiannya akan dibahagi-bahagikan antara mereka. 
Perkembangan ekonomi baru yang diperkenalkan oleh pihak BNBC ini juga telah menyebabkan wujudnya beberapa kelompok kecil masyarakat Melayu Brunei yang telah berhijrah ke bahagian utara Borneo seperti Kudat, Tawau, Sandakan dan lain-lain lagi. Penawaran pekerjaan di kawasan tersebut merupakan tarikan utama mereka untuk berhijrah. Lazimnya, apabila berhijrah mereka akan membawa bersama ahli keluarga mereka dan apabila ekonomi mereka semakin stabil, mereka akan mengajak saudara-mara mereka untuk tinggal bersama. Situasi ini secara tidak langsung telah menyebabkan wujudnya penempatan atau perkampungan kecil masyarakat Melayu Brunei di bahagian utara Borneo. (Datuk Haji Yusoff, 2010). Di Kudat umpamanya, penempatan masyarakat Melayu Brunei bermula pada tahun 1905 yang terletak di Kampung Air. ${ }^{\text {xii }}$ Penempatan ini berlaku disebabkan oleh tarikan ekonomi yang diperkenalkan oleh pihak BNBC. Penglibatan masyarakat Melayu Brunei di dalam sektor perikanan, pertanian, perusahaan perladangan kelapa dan menjadi buruh pembinaan jalan raya dari Kudat sehingga ke Sikuati telah menyebabkan mereka menjadi penyumbang terbesar kepada ekonomi Kudat pada tahun 1930-an (Saat \& Jumilah, 2015:67-68).

\section{Impak Sosial}

\section{Perubahan Status dan Gelaran}

Perubahan penempatan masyarakat Melayu Brunei pada awalnya tidak melupuskan penggunaan status gelaran mereka. Hal ini kerana lazimnya masyarakat ini hanya akan hidup bersama dengan kaum kerabat dan saudara-maranya sahaja memandangkan mereka bukan sahaja tidak membenarkan kaumkaum lain untuk membina penempatan bersama mereka malah perkahwinan campur juga tidak dibenarkan dalam keturunannya. Perlu difahami bahawa masyarakat Melayu Brunei sememangnya terkenal dengan kepelbagaian gelaran yang diwarisi secara turun-temurun untuk menentukan kedudukan dan peranan mereka dalam hierarki masyarakat. Gelaran Ampuan ${ }^{\text {xii }}$ dan Pengiran $^{\mathrm{xiv}}$ merupakan status gelaran yang diperoleh sama ada daripada keturunan yang mempunyai perkaitan dengan darah diraja, penganugerahan Sultan ataupun melalui cara pembelian gelaran. Hal ini terbukti apabila wujudnya pembahagian terhadap golongan bangsawan di Brunei iaitu golongan bangsawan yang berdarah raja dan golongan yang tidak berdarah raja. Golongan bangsawan yang tidak berdarah raja dikategorikan sebagai golongan aristokrat yang memperoleh gelaran melalui penganugerahan dan terdapat juga sebilangan mereka bertindak membeli gelaran-gelaran tersebut untuk menaikkan status sosial mereka dalam kalangan masyarakat (Sabihah, Muhammad \& Sabullah, 2001: 19-20; Bilcher, 2011: 53).

Selain daripada gelaran Ampuan dan Pengiran, masyarakat Melayu Brunei juga turut menggunakan gelaran Awang dan Dayang. Golongan yang diberikan gelaran Awang-awang merupakan golongan yang paling dekat dengan istana. Mereka mempunyai kedudukan yang tinggi dan terhormat dalam kalangan masyarakat Melayu Brunei. Kebanyakan mereka memperoleh gelaran ini daripada penganugerahan Sultan. Golongan rakyat biasa pula merupakan golongan yang terbanyak dalam masyarakat Melayu Brunei. Mereka secara keseluruhannya tidak mempunyai apa-apa gelaran tetapi mereka memanggil golongan biasa ini dengan panggilan 'Awang' bagi lelaki dan 'Dayang' bagi perempuan. Gelaran ini merupakan gelaran umum dalam kalangan masyarakat Melayu Brunei (Sabihah, Muhammad \& Sabullah, 2001: 21).

Sebelum Borneo Utara ditadbir oleh pihak BNBC, kebanyakan masyarakat Melayu Brunei yang menetap di Benoni, Buang Sayang, Membakut dan Bongawan mengamalkan kehidupan yang terpencil dan enggan untuk tinggal bersama dengan kaum lain. Namun begitu, disebabkan oleh pendedahan ekonomi yang dilakukan oleh pihak BNBC maka mereka mulai berhubung dan berasimilasi dengan kaum-kaum lain. Walau bagaimanapun, dari sudut perkahwinan sebahagian besar golongan ini masih lagi tidak membenarkan perkahwinan campur dilakukan kerana untuk mengelakkan daripada hilangnya gelaran yang dibawa oleh keturunan mereka (Ampuan Mumin, 2010). Walau bagaimanapun, disebabkan oleh pendedahan penjajah terhadap aspek pemodenan dan peningkatan tahap pendidikan dalam kalangan masyarakat Melayu Brunei maka persepsi mereka terhadap status gelaran juga semakin berubah. Situasi ini juga mungkin berlaku disebabkan oleh usaha pihak penjajah untuk menggalakkan kemasukan kaum lain ke kawasan yang diduduki oleh majoritinya masyarakat Melayu Brunei. Tujuan utama pihak penjajah melakukan sedemikian adalah untuk mempelbagaikan kaum yang menetap di 
kawasan-kawasan tersebut di samping berusaha untuk menggalakkan perkahwinan campur dalam kalangan masyarakat Melayu Brunei. Selain itu, kesedaran dalam kalangan masyarakat Melayu Brunei ini juga timbul apabila mereka mulai menerima kepelbagaian kaum yang wujud di sekeliling mereka dan memahami bahawa gelaran dalam keturunan mereka itu tidak lagi membawa apa-apa makna serta keistimewaan yang boleh mereka banggakan sepertimana pada zaman pemerintahan Kesultanan Brunei.

Gelaran dalam kalangan masyarakat Melayu Brunei ini juga semakin terhakis apabila kebanyakan masyarakat Melayu Brunei yang mempunyai status kebangsawanan ini hanya menjadi petani dan nelayan. Walau bagaimanapun, dalam hal ini kaum-kaum lain tetap mengiktiraf gelaran dan keturunan yang ada dalam kalangan masyarakat Melayu Brunei kerana perasaan saling hormat-menghormati di antara satu-sama lain. Rentetan itu, penggunaan gelaran tersebut tidak lagi begitu dititikberatkan oleh masyarakat Melayu Brunei yang memiliki status kebangsawanan ini kerana mereka menganggap bahawa gelaran itu tidak lagi penting dan membawa sebarang perubahan serta keistimewaan biarpun mereka menggunakan dan mengekalkannya. Oleh yang demikian itu, maka kebanyakan daripada mereka ini lebih gemar untuk menjadikan gelaran tersebut sebagai suatu "pilihan" sama ada ingin menambah ataupun menggugurkannya adalah terpulang kepada kehendak individu masing-masing. Kesannya, gelaran yang ada pada mereka itu hanya menjadi "hiasan" di bahagian pangkal nama sahaja tanpa mengetahui fungsi dan penggunaan sebenar gelaran itu. Keadaan ini telah menyukarkan individu lain untuk mengenali mereka kecuali melalui pertuturan dan latar belakang keluarganya.

\section{Penglibatan dalam Sistem Pendidikan formal}

Sewaktu era pemerintahan Kesultanan Brunei di kawasan pantai barat utara Borneo, aspek pendidikan masyarakat Melayu Brunei tidaklah begitu dititikberatkan memandangkan fokus utama pihak pentadbir hanyalah untuk berdagang dan menjadi tuan tanah untuk mendapatkan cukai daripada penduduk sahaja. Oleh itu, tidak wujud sebarang bentuk sistem pendidikan formal melainkan pengajaran ilmu keagamaan yang dijalankan oleh golongan ulama, imam dan ustaz. Golongan pengajar ini kebanyakannya merupakan pelajar dari Timur Tengah yang kemudiannya mengajar penduduk beragama Islam untuk memperdalami ilmu keagamaan yang memfokus kepada ajaran ilmu fardhu ain dan fardhu kifayah di surau (Jatswan,1995: 83; Sabihah, 1981: 3).

Pentadbiran BNBC telah memulakan sistem pendidikan secara formal bagi mengatasi masalah buta huruf dalam kalangan penduduknya. Kewujudan sistem persekolahan ini adalah selaras dengan peruntukkan pendidikan yang terkandung di dalam piagam syarikat berkenaan. Terdapat dua objektif utama yang mendasari sistem pendidikan di Borneo Utara iaitu pertama meningkatkan tahap pengetahuan membaca, menulis dan mengira dalam kalangan penduduk di samping memberikan latihan teknikal untuk meningkatkan kemahiran masyarakat peribumi dalam bidang pekerjaan utama mereka. Objektif kedua pula ialah untuk menyediakan pendidikan bagi anak-anak Ketua Anak Negeri (KAN) sebagai persediaan mereka untuk bekerja kemudiannya (Siti Aidah, 2007: hlm. 80).

Secara realistiknya, pihak BNBC hanya berminat untuk memberikan pendidikan asas atau dasar kepada masyarakat peribumi sahaja. Dalam hal ini, penjajah hanya akan memberikan peluang kepada anak-anak peribumi agar lebih pandai sedikit daripada ibu bapa mereka. Pendidikan formal di kawasan Pantai Barat hanya bermula pada tahun 1915 apabila pihak BNBC membina sekolah untuk anak-anak KAN yang pertama di Jesselton. Pembinaan sekolah ini adalah bertujuan untuk memberikan pendedahan kepada anak-anak ketua tempatan tentang tugas-tugas pentadbiran di samping melatih mereka supaya menjadi KAN sepertimana bapa mereka. Bagi anak-anak masyarakat Melayu Brunei di kawasan Papar, mereka tidak diberikan peluang untuk mengikuti pendidikan di sekolah KAN kerana kemasukan pelajar ke sekolah ini adalah terhad dan ketat serta hanya disediakan untuk anak-anak KAN sahaja ${ }^{x v}$ Walau bagaimanapun, pada tahun 1918 penghantaran anak-anak KAN ke sekolah ini semakin berkurangan sehingga sekolah tersebut terpaksa ditutup pada tahun 1930. Situasi ini berlaku ekoran kurangnya minat dan sokongan daripada ketua-ketua tempatan terhadap sekolah tersebut (Nor, 1978: 8-9; Sabihah, 12-15; Tregoning, 2007: 217-218).

Pada peringkat awal, kebanyakan lokasi sekolah khususnya sekolah bantuan kerajaan (Missionary) terletak di kawasan yang menjadi pusat utama kepada sumber ekonomi komersial BNBC. Hal ini kerana 
pusat-pusat ini bukan sahaja menjadi tumpuan peniaga dan pelabur tetapi juga mempunyai kemudahan infrastruktur yang baik. Di kawasan Papar dan Putatan umpamanya, Sekolah bantuan kerajaan telah ditubuhkan untuk memberikan kemudahan pendidikan kepada penduduknya. Dalam hal ini, masyarakat Melayu Brunei lebih berminat untuk menghantar anak-anak mereka bersekolah di sekolah rendah kerajaan berbanding dengan sekolah bantuan kerajaan ${ }^{\mathrm{xvi}}$ kerana yurannya yang sangat mahal dan kebimbangan anak-anak mereka akan terpengaruh dengan agama Kristian. ${ }^{\text {xvii }}$ Di kawasan pantai barat, penubuhan sekolah rendah kerajaan hanya berlaku antara tahun 1921 sehingga tahun 1922 apabila kerajaan BNBC menubuhkan sekolah vernakular di Kota Belud, Kudat, Jesselton, Tuaran dan Papar. Penubuhan sekolah ini juga telah memberikan peluang kepada anak-anak masyarakat Melayu Brunei untuk mendapatkan pendidikan formal selepas tidak terpilih untuk mengikuti pendidikan di sekolah KAN. Meskipun begitu, bilangan masyarakat Melayu Brunei yang bersekolah pada tahun 1922 sehinggalah tahun 1925 masih lagi sangat rendah berbanding dengan kaum-kaum lain. Pada tahun 1926, keadaan tersebut mulai berubah kerana berlakunya peningkatan bilangan pelajar yang mendadak dalam kalangan masyarakat Melayu Brunei berikutan tindakan pihak BNBC melantik Imam untuk mengajar al-Quran di sekolah tersebut (Sabihah, 1981:26-27).

Menjelang tahun 1930, terdapat 10 buah sekolah Melayu telah ditubuhkan di Borneo Utara dengan bilangan pelajar seramai 391 orang murid lelaki. Pada tahun 1935 pula, pakaian seragam sekolah telah diperkenalkan di sekolah-sekolah kerajaan. Pada waktu itu, latihan jasmani dan pekerjaan kebun turut diajar di sekolah-sekolah. Program berkebun ini diadakan di sekolah-sekolah kerajaan untuk mengajar pelajar lelaki menanam tanaman makanan dengan kaedah penanaman yang lebih baik untuk meningkatkan pengeluarannya. Selain itu, program ini juga bertujuan untuk mendedahkan para pelajar memakan hasil tanaman mereka sendiri untuk kepentingan kesihatan mereka. Hasil tersebut juga tidak boleh dijual atau diberikan kepada orang lain (Siti Aidah, 2007: 83; Sabihah, 1981: 26-27).

Perlu diketahui bahawa biarpun sistem pendidikan formal telah meningkat semasa era pentadbiran BNBC, namun masih wujud kekangan yang ketara daripada ibu bapa terutamanya dalam membenarkan anak-anak perempuan mereka untuk pergi ke sekolah. Selain itu, kerajaan BNBC juga tidak mengesyorkan bahasa Inggeris diajar di sekolah Melayu kerana mereka khuatir akan lahirnya masyarakat yang berpendidikan tinggi. Hal ini kerana sekiranya kaum peribumi ini diberi peluang untuk mendapatkan pendidikan yang tinggi, mereka tidak akan kembali ke kampung halaman mereka untuk bekerja sebagai petani dan nelayan sebaliknya mengharapkan pekerjaan yang setaraf dengan kelulusan mereka. Pihak BNBC juga bimbang sekiranya pendidikan yang tinggi diberikan kepada masyarakat peribumi akan wujud kesedaran dan tentangan daripada masyarakat peribumi. Oleh itu, pihak BNBC sentiasa menolak tuntutan para KAN untuk meminta bahasa Inggeris diajar di sekolah Vernakular kerajaan. Bermula dari tahun 1935, tokoh kepimpinan peribumi Majlis Penasihat Ketua Anak Negeri (MPKAN) begitu lantang menyuarakan keinginan mereka supaya bahasa Inggeris diajar di sekolahsekolah Melayu untuk membolehkan mereka bersaing dan mendapatkan peluang untuk belajar di sekolah menengah dan menjawat jawatan penting dalam perkhidmatan awam. Salah seorang KAN dalam kalangan Melayu Brunei yang lantang bersuara untuk menuntut supaya bahasa Inggeris diajarkan di sekolah-sekolah Melayu ialah O.K.K Pengiran Serudin. Namun begitu, tuntutan beliau ini ditolak oleh pihak BNBC. Sistem pendidikan formal yang diperkenalkan oleh pihak BNBC ini tetap dikekalkan tanpa sebarang perubahan sehinggalah tercetusnya Perang Dunia Kedua 1942.

\section{Peningkatan Tahap Kesihatan}

Sebelum pihak BNBC mengambil alih pemerintahan di Borneo Utara, tidak wujud pusat kesihatan di kawasan pantai barat. Pada waktu itu, kebanyakan masyarakat Melayu Brunei bergantung kepada amalan perubatan tradisional yang dikendalikan oleh dukun, pawang dan bomoh untuk mengubati pelbagai penyakit. Keadaan ini telah menyebabkan kadar kematian dalam kalangan masyarakat Melayu Brunei sangat tinggi. Namun begitu, keadaan tersebut mulai berubah apabila kerajaan BNBC mengambil alih Borneo Utara dari Kesultanan Brunei dan Kesultanan Sulu. Sewaktu pentadbiran BNBC, mereka telah membina hospital dan beberapa buah dispensari bergerak di Kudat, Kota Belud, Kota Marudu dan Jesselton pada tahun 1920-an bagi memenuhi keperluan para pegawai dan kakitangan BNBC di kawasan pantai barat. ${ }^{\text {xiii }}$ Di Kudat umpamanya, pejabat kerajaan telah dijadikan sebagai Rumah Sakit yang diperlengkap dengan pelbagai kemudahan seperti dapur dan tandas untuk kegunaan pelawat dan pesakit. Rumah Sakit tersebut juga boleh memuatkan seramai 30 hingga 45 orang pesakit 
yang menghidapi pelbagai peringkat dan jenis penyakit dengan penyediaan kemudahan yang lengkap termasuklah katil dan bilik bedah. Bagi masyarakat Melayu Brunei yang tinggal jauh di pedalaman dan bekerja di estet, pihak kerajaan BNBC telah menghantar bantuan ubat-ubatan ke kawasan tersebut dengan menggunakan perahu dan kumpit (Hazimah, 1998: 49-52).

Pihak BNBC juga turut berusaha untuk menggalakkan masyarakat peribumi supaya mengetahui asasasas penjagaan kebersihan dan langkah-langkah bagi menggelakkan daripada berlakunya jangkitan penyakit seperti malaria, tibi, batuk kering, kusta, cirit-birit, puru, radang paru-paru, beri-beri dan sebagainya. Kebanyakan masyarakat peribumi khususnya masyarakat Melayu Brunei yang tinggal di kawasan ladang lebih terdedah kepada jangkitan penyakit tersebut kerana lazimnya kes penyakit malaria di kawasan Pantai Barat lebih tertumpu di Mawao Estate, Lumat Estate, Membakut Estate, Beaufort Estate dan Kimanis Estate yang kebanyakan buruhnya terdiri daripada masyarakat Melayu Brunei yang menetap di Kimanis, Benoni, Membakut dan Bongawan. Estet ini sering menunjukkan turun naik kadar kematian disebabkan oleh penyakit malaria, beri-beri dan cirit-birit (British North Borneo Annual Report, 1919, 1921, 1922, 1924, 1926). Oleh itu, usaha untuk meningkatkan tahap kesihatan dalam kalangan masyarakat Melayu Brunei yang tinggal di kawasan ladang khususnya di Kimanis, Membakut, Putatan, Jesselton dan Kudat masih lagi sukar untuk dilaksanakan secara meluas oleh pihak BNBC kerana aspek kesihatan ini banyak dipengaruhi oleh cara penyelenggaraan majikan di kawasan ladang. Kepentingan kesihatan tenaga buruh estet merupakan antara elemen penting yang dititikberatkan oleh pihak majikan semasa zaman BNBC. Hal ini kerana sekiranya ramai tenaga buruh yang dijangkiti penyakit, maka kuantiti pengeluaran tidak akan dapat ditingkatkan. Kempen kesihatan untuk memperkenalkan perubatan moden dalam kalangan Masyarakat Melayu Brunei ini menempuhi pelbagai kesukaran memandangkan masyarakatnya tidak meyakini sistem perubatan moden tetapi sebaliknya lebih mempercayai dukun dan bomoh.

Dipensari bergerak di kawasan Papar hanya diwujudkan pada tahun 1930. Oleh itu, sebelum wujudnya dispensari tersebut, kebanyakan masyarakat Melayu Brunei yang tinggal di kawasan Papar menggunakan perubatan tradisional untuk mengubati penyakit. Keadaan ini menyebabkan bilangan kematian dalam kalangan masyarakat Melayu Brunei khususnya kelahiran bayi pra matang dan jangkitan penyakit semakin meningkat. Hal ini terbukti berdasarkan jumlah populasi masyarakat Melayu Brunei yang tidak banyak berubah dari tahun 1911 sehinggalah tahun 1921. Berdasarkan kenyataan informan Ampuan Mumin Bin Ampuan Tuah, sewaktu pemerintahan BNBC pihak hospital telah menghantar jururawat ke rumah untuk memeriksa kesihatan penduduk di samping membekalkan sabun mandi, ubat gigi dan sabun pencuci secara percuma kepada penduduk supaya penduduk sentiasa menjaga kebersihan. Meskipun pada awalnya lawatan para jururawat ke kampung ini disambut dingin oleh penduduk kampung namun, selepas mereka melakukan pelbagai kempen dan ceramah tentang penjagaan kesihatan dan ancaman pelbagai jenis penyakit berpunca daripada masalah kebersihan maka lebih ramai penduduk kampung yang tampil untuk mendapatkan rawatan moden. Pemberian kemudahan rawatan dan pengedaran ubat-ubatan secara percuma ini dikekalkan sehinggalah tamatnya pentadbiran BNBC di Borneo Utara pada tahun 1942.

\section{Kesimpulan}

Perubahan penempatan masyarakat Melayu Brunei di kawasan pantai barat Borneo Utara telah memberikan impak terhadap penglibatan mereka di dalam aspek ekonomi dan sosial selepas diambil alih oleh pihak BNBC. Sebelumnya, masyarakat Melayu Brunei sinonim dengan aktiviti maritim iaitu perdagangan dan perikanan. Keadaan ini kemudiannya berubah, mereka terlibat dalam sektor ekonomi berasaskan persawahan, perladangan dan perburuhan. Penglibatan masyarakat Melayu Brunei dalam ekonomi komersial ini bukan sahaja telah membawa masyarakat ini berhijrah ke kawasan pantai timur Borneo Utara tetapi juga telah menyebabkan mereka berpindah dari kawasan persisiran pantai dan sungai ke kawasan tanah datar yang sesuai untuk aktiviti pertanian. Selain itu, pembangunan pelbagai kemudahan sosial di Borneo Utara juga turut memberikan impak terhadap peningkatan tahap pendidikan, kesihatan. Pada masa yang sama persepsi masyarakat ini terhadap aspek status gelaran tradisional yang diwarisi sekian lama mula berubah dan hidup berasimilasi dengan masyarakat lain. Mereka turut menerima elemen pemodenan yang dibawa oleh pihak BNBC dalam aspek politik, ekonomi dan sosial 
tanpa pertentangan yang dibuktikan tidak wujud sebarang kebangkitan penentangan atau pemberontakan dalam kalangan masyarakat Melayu Brunei kerana sistem barat yang diperkenalkan.

\section{Nota Hujung}

${ }^{\mathrm{i}}$ Melalui perjanjian tersebut, BNBC telah berjaya meletakkan sempadan daerah-daerah yang berada di bawah naungan kekuasaan politik dan ekonomi mereka. Hal ini membuktikan bahawa di bawah perjanjian tersebut, kedudukan BNBC di Borneo Utara bukan sahaja diiktiraf oleh kesultanan Brunei malah mereka juga tidak pernah mengetepikan hak dan pembabitan Sultan Brunei dalam memperoleh wilayah dan kawasan di Borneo Utara. Pada tanggal 12 Mei 1888, Borneo Utara telah menjadi milik pihak BNBC sepenuhnya. Hal ini bermakna bahawa hampir keseluruhan sistem pentadbiran Kesultanan Brunei diletakkan di bawah sistem pemerintahan pihak BNBC.

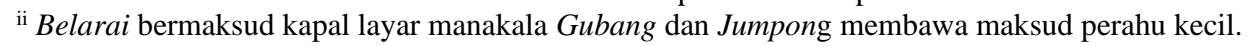

iii Ampuan Mumin Bin Ampuan Tuah merupakan cicit kepada Ampuan Ismail Bin Ampuan Amin iaitu imam kedua di Kampung Benoni yang dilantik oleh Sultan Hashim Jalilul Aqamaddin. Ampuan Ismail telah berkahwin dengan Dayangku Siti Hajar yang berasal dari Kampung Limau Manis Brunei Darussalam dan melahirkan anak tunggalnya iaitu Ampuan Itam. Ampuan Itam kemudiannya berkahwin dengan Dayang Banun dan melahirkan Ampuan Tuah yang merupakan bapa kepada Ampuan Mumin. Ampuan Mumin Bin Ampuan Tuah merupakan generasi ke-4 Keturunan Ampuan Amin (Mat Amin) yang pernah dilantik menjadi pembesar di istana Brunei.

iv Golongan yang berdarah Raja/Sultan.

${ }^{v}$ Golongan tidak berbangsa dan berketurunan.

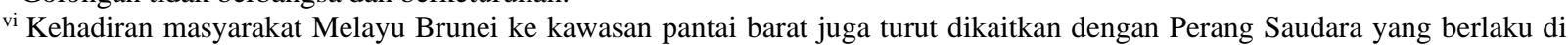
negara Brunei pada tahun 1661. Peristiwa ini tercetus apabila Raja Bungsu putera Sultan Muhammad Ali (T.M 16601661) telah membunuh Raja Dungu iaitu anak kepada Pengiran Bendahara Abdul Mubin kerana beliau telah merasa malu apabila kalah bersabung ayam dengan anak Pengiran Bendahara. Situasi ini telah menyebabkan Pengiran Bendahara bertindak membalas dendam atas kematian anaknya. Oleh kerana Raja Bungsu telah melarikan diri, maka Sultan Muhammad Ali telah menggantikan tempat puteranya dan baginda telah dibunuh oleh Pengiran Bendahara dengan cara dikujut pada 8 Mei 1648 Masihi. Selepas Sultan Muhammad Ali mangkat, Pengiran Bendahara Abdul Mubin telah melantik dirinya sebagai Sultan Brunei ke-13 dengan gelaran Sultan Hakkul Mubin (1661-1673). Pengiran Muhyiddin putera kepada Sultan Jalilul Akbar (T.M 1598-1659) iaitu menantu kepada Sultan Muhammad Ali telah dilantik menjadi Pengiran Bendahara. Walaupun beliau diberikan jawatan tinggi dalam kerajaan, namun dengan dorongan dan bantuan Orang Kaya Besar Imas, iaitu seorang Manteri Kedayan telah merancang untuk membalas dendam atas kemangkatan bapa mertuanya. Para pengikut Pengiran Bendahara telah bertindak membuat huru-hara dan kekecohan di dalam istana Brunei. Dalam keadaan huru-hara tersebut Pengiran Bendahara telah mencadangkan supaya Sultan Hakkul Mubin berpindah ke Pulau Chermin yang terletak di Muara Sungai Brunei. Sewaktu ketiadaan Sultan Hakkul Mubin di pusat pemerintahan Brunei maka Sultan Muhyiddin telah mengambil kesempatan tersebut untuk mengisytiharkan dirinya sebagai Sultan Brunei ke-14. Tindakan Pengiran Bendahara menimbulkan kemarahan kepada Sultan Hakkul Mubin sehingga mencetuskan Perang Saudara. Peperangan tersebut berlanjutan selama 12 tahun dan telah membawa kekalahan kepada Sultan Hakkul Mubin. Walau bagaimanapun, sebelum baginda dibunuh, baginda telah mengarahkan agar semua harta kerabat diraja dimusnahkan, termasuklah permata mahkota asal Brunei yang telah dimasukkan ke dalam meriam dan ditembakkan ke Laut China Selatan. Ekoran daripada Perang Saudara tersebut wujudnya suasana yang tidak aman di Brunei. Situasi ini telah menyebabkan ramai rakyat Brunei berhijrah ke bahagian Pantai Barat utara Borneo seperti Sipitang, Menumbok, Weston, Bongawan dan Papar. Di tempat tersebut mereka kemudiannya membina kehidupan yang baru dengan mengekalkan ciri-ciri hidup yang telah diamalkan di Brunei. Selain itu, mereka juga tidak mahu kembali semula ke negara Brunei disebabkan oleh keselesaan hidup dan keselamatan yang lebih terjamin di kawasan baru mereka.

vii Pengiran Muluk (Pengiran Anak Damit atau Pian Anak Damit) merupakan bapa kepada Pengiran Omar atau lebih dikenali sebagai Apong Damit iaitu imam pertama di Kampung Benoni. Pengiran Anak Damit telah berkahwin dengan Pengiran Sarah atau dikenali sebagai Pengiran Seri Gantisan dari Karambunai pada usia 52 tahun. Di Benoni, Pengiran Anak Damit dikenali sebagai Pengiran Apong Besar. Hasil Perkahwinan tersebut telah melahirkan Pengiran Omar dan Dayang Lipah. Apabila Pengiran Omar dilantik menjadi imam pertama di Kampung Benoni, beliau telah menolak untuk mewarisi Karambunai dan perwarisan Karambunai terpaksa diserahkan kepada sepupunya iaitu Pengiran Fatimah. Di Benoni, anak kepada Pengiran Anak Damit iaitu Pengiran Omar diberikan gelaran sebagai Pengiran Apong Damit yang bermaksud nibung. Pengiran Omar kemudiannya berkahwin dengan Ampuan Aminah dan melahirkan tiga orang anak lelaki dan seorang anak perempuan iaitu Pengiran Haji Hassan, Pengiran Haji Ismail, Pengiran Kassim dan Dayang Sarah. Mereka inilah kerabat istana tulin yang diperakui oleh Sultan Omar Saiffuddin III sewaktu pemerintahannya.

viii Pembukaan penempatan oleh masyarakat Melayu Brunei ini telah menyebabkan wujudnya pusat operasi wakil Sultan yang berperanan sebagai pentadbir di wilayah berkenaan. Pusat operasi berkenaan terletak di beberapa tempat iaitu; Sebuah di Benoni, dua buah di Kimanis, tiga buah di Membakut dan empat buah di Kinarut.

ix The Borneo, Hong Ann, Banda, Thales dan RoyAllist.

${ }^{x}$ Kawasan Perusahaan ladang getah di Papar melibatkan Kampung Benoni dan Kampung Berunai. Di Bongawan pula melibatkan Kampung Tarap, Kampung Tengah dan Kampung Laut manakala perusahaan ladang getah di Membakut melibatkan Kampung Mawao dan Kampung Pimping. Walau bagaimanapun, pekerja-pekerja estet ini tidak semuanya berasal dari tempat-tempat tersebut kerana terdapat juga sebahagian mereka berasal dari Kimanis, Beaufort, Benoni dan Bongawan. Mereka bekerja di estet-estet berkenaan berdasarkan peluang kerja dan lokasi ladang yang berdekatan dengan tempat tinggal mereka.

xi Istilah Pesagi merujuk kepada sekumpulan pekerja yang diupah bekerja sebagai pemotong kayu balak semasa zaman pemerintahan British. 
xii Pada tahun 1881, sekumpulan British bersama masyarakat Melayu Brunei telah datang untuk membuka Kudat. Kudat telah dijadikan sebagai Ibu Pejabat Pentadbiran BNBC pada tahun 1882. Namun begitu, Ibu Pejabat BNBC ini hanya bertahan selama 2 tahun sahaja disebabkan oleh kekurangan sumber air sehingga menyebabkan BNBC terpaksa memindahkan pusat pentadbiran mereka ke Sandakan. Penempatan pertama masyarakat Melayu Brunei di Kampung Air dibuka oleh Pengiran Ibrahim Bin Pengiran Arshad pada tahun 1903. Sebelum beliau menetap di Kudat beliau terlebih dahulu menetap di Mengkabong, Tuaran kerana menjalankan perniagaan jual beli tembaga. Pada awalnya, Kampung Air merupakan sebuah kawasan hutan dipesisir laut pekan Kudat yang berfungsi sebagai tempat penyimpanan kayu balak. Pada peringkat awal hanya 5 buah rumah yang dibina di kawasan tersebut. Pada tahun 1914, Pengiran Ibrahim telah menggalakkan ahli keluarganya yang tinggal di Kampung Patau-Patau Labuan supaya berhijrah ke Kudat. Pada tahun 1920-an, Kampung Air telah menjadi sebuah perkampungan yang luas sehingga mencecah 20 buah rumah.

xiii Golongan Ampuan merupakan golongan yang mempunyai status sosial yang tinggi dalam masyarakat. Golongan ini juga dikatakan mempunyai pelbagai masalah dalam asal keturunan mereka kerana kebanyakan daripada golongan Ampuan ini menetap di tempat yang jauh dan berasingan sehingga menimbulkan masalah dalam keturunannya. Pada akhir abad ke19, mereka ini juga turut digolongkan dalam kalangan golongan bangsawan. Umpamanya, dalam sesuatu upacara penabalan anak-anak raja atau lebih dikenali sebagai perpuspaan atau perkahwinan diraja, golongan Ampuan ini ditugaskan untuk membawa atau menyandang peralatan kelengkapan diraja yang diperlukan dalam sesuatu majlis seperti mengangkat usungan atau kenderaan diraja. Gelaran Ampuan ini terbahagi kepada dua golongan iaitu Ampuan 'bertaras' yang berketurunan darah diraja dan golongan Ampuan 'kebanyakan' yang memperolehi gelaran tersebut melalui cara penganugerahan Sultan atau pembelian gelaran. Pembelian gelaran merupakan satu istilah yang diberikan oleh masyarakat Melayu Brunei kepada golongan bangsawan terpelajar yang telah bertindak menggunakan gelaran Ampuan atau Pengiran untuk mendapatkan pengiktirafan dan penghormatan daripada masyarakat Melayu Brunei. Gelaran ini juga biasanya dibeli oleh golongan kedatuan etnik Suluk yang merupakan ketua dalam kalangan masyarakat Suluk.

${ }^{\text {xiv }}$ Gelaran Pengiran merupakan gelaran yang diberikan kepada golongan bangsawan Brunei yang berasal daripada kerabat diraja. Namun begitu, bagi golongan yang mempunyai gelaran Pengiran tetapi bukan dari keturunan diraja dikenali sebagai Pengiran Kebanyakan. Mereka ini merupakan golongan yang tidak diketahui jurai keturunannya daripada keturunan asal. Keadaan ini wujud disebabkan oleh perkembangan masa, penduduk dan faktor sosial.

${ }^{x v}$ Pemilihan anak-anak Ketua Tempatan dibuat oleh residen dan ketua-ketua dari seluruh pelusuk Borneo Utara iaitu dari Tawau sehinggalah ke Papar. Kebanyakan mereka yang terpilih ini berusia dalam lingkungan 9-25 tahun. Mereka akan diberikan kursus selama 3 tahun untuk mengikuti kursus tertentu mengukut sukatan pelajaran yang telah ditetapkan oleh Jabatan Pelajaran Negeri-negeri Selat.

${ }^{x v i}$ Pihak BNBC telah menubuhkan sekolah persendirian dan sekolah mubaligh seperti Roman Katholik dan Basel di Putatan selepas tahun 1920-an. Walau bagaimanapun, sekolah-sekolah Roman Katholik ini hanya dikendalikan di daerah Sandakan, Kudat, Tawau dan Jesselton sahaja manakala sekolah mubaligh Basel telah dibina di Putatan. Pada peringkat awal, Sekolah Basel ini merupakan satu-satunya sekolah yang wujud di Putatan. Sekolah St. Peter merupakan sekolah lelaki pertama yang menggunakan bahasa Inggeris dan Dusun sebagai bahasa pengantar. ${ }^{x i}$ Menyedari akan kepentingan pembinaan sekolah ini, maka Masyarakat Islam yang terdiri daripada masyarakat Melayu Brunei mula aktif membina madrasah dan surau untuk dijadikan tempat menuntut ilmu bagi masyarakat Islam. Surau dan madrasah ini telah dibina oleh penduduk kampung dengan cara bergotong-royong.

xvii Berdasarkan pengalaman informan Ampuan Mumin Bin Ampuan Tuah yang pernah bersekolah di sekolah bantuan kerajaan St. Joseph Papar, bayaran yuran yang dikenakan ialah 25 sen sehari. Selepas tamat persekolahan, beliau telah ditawarkan untuk bekerja sebagai tukang sukat di Jesselton. Namun begitu, disebabkan oleh kedudukannya yang agak jauh dari tempat tinggal dan kebimbangan daripada ibu bapa beliau tentang keselamatannya, maka beliau telah menolak tawaran tersebut dan bekerja sebagai petani untuk membantu keluarga.

xviii Dispensari Kolam Ayer merupakan dispensari pertama yang diwujudkan di kawasan Pantai Barat. Pada awalnya dispensari ini diuruskan oleh Dresser Grade III iaitu Edmund Ten Fatt yang telah merawat 1260 kes yang melibatkan 67 buah perkampungan tempatan yang dilawati sepanjang pertengahan tahun 1920-an. Dispensari ini terletak tiga batu dari Jesselton dan pada tahun 1922 bilangan pesakit yang dirawat dilaporkan seramai 1614 orang. Kota Belud dan Kudat juga mempunyai dispensarinya yang tersendiri. Dispensari di Kota Belud umpamanya terletak di Daerah Keppel dan diuruskan oleh Dresser Grade II yang banyak melakukan lawatan ke daerah sekitarnya. Bilangan pesakit yang dirawat ialah seramai 1729 orang. Dispensari di Kota Belud ini pernah dilawat oleh Pegawai Perubatan Dr. Percival A. Dingle pada tahun 1923 disebabkan oleh masalah penyakit cacar dalam kalangan kanak-kanak yang melibatkan 54 buah kampung. Kudat juga mempunyai kemudahan dispensarinya tersendiri dan Hospital Awam. Dispensari Langkon terletak di kawasan Teluk Marudu telah memulakan perkhidmatannya pada bulan Mei 1924. Dispensari ini diuruskan oleh seorang Pembantu Perubatan berbangsa Cina iaitu Dresser Grade III di bawah seliaan Dr. Morris Schwartz yang berperanan melawat dispensari ini dua kali sebulan. Rawatan bagi penduduk tempatan di dispensari ini akan diberikan secara percuma. Namun demikian, dispensari ini telah ditutup pada 31 Disember 1923 disebabkan oleh wujudnya Hospital Awam Jesselton.

\section{Rujukan}

Ampuan Mumin Bin Ampuan Tuah. (2010). 96 Tahun. Kampung Benoni Papar. Temubual 24 April 2010.

Awang Haji Abdul Latif bin Haji Ibrahim. (1989). Sejarah dan Tradisi di Brunei. Brunei Darussalam: Jabatan Pusat Sejarah Kementerian Kebudayaan Belia dan Sukan. 
Bala, B. (2011). Satu Sejarah Migrasi Masyarakat Melayu Brunei Ke Sabah. Seminar Sejarah Borneo Ke-2. 19-12 Oktober 2011. Pusat Sejarah Brunei, Brunei Darussalam.

British North Borneo Annual Report. (1914).

British North Borneo Annual Report. (1921).

British North Borneo Annual Report. (1922).

British North Borneo Annual Report. (1924).

British North Borneo Annual Report. (1926).

British North Borneo Herald. (1883).

British North Borneo Herald. (1888).

Brown, D.E. (1970). Brunei: The Structure and History of A Bornean Malay Sultanate. Monograph of the Brunei Museum Journal.

Carroll, S. J. (1982). Berunai in the Boxer Codex. JMBRAS. Vol. LV. Part 2. 1-3.

Colony of North Borneo Official Gazette. (1926).

Datuk Haji Yusoff Bin Datuk Seri Panglima Haji Mohd. Kassim. (2010). Presiden Persatuan Melayu Brunei Sabah ( PMBS). King Fisher Kota Kinabalu. Temubual 21 Februari 2010.

Fail Daerah Papar, Membakut dan Bongawan; Arkib Negeri Sabah.

Haji Zaini Bin Haji Ahmad. (1983). Pertumbuhan Nasionalisme di Brunei (1939-1962). Kuala Lumpur: ZR Publication.

Hazimah Awang Damit. (1998). Sejarah Kesihatan Di Sabah 1881-1941. Latihan Ilmiah Sarjana Muda. Universiti Malaya.

Keith, H.G. (1980). The Monograph of the Brunei Museum Journal the United States Consul and the Yankee Raja. Brunei Darussalam: The Brunei Museum.

Marilyn Johny, Mohamad Shauki Mohd Radzi, Mosli Tarsat. (2015). Penentangan Pemimpin Tempatan terhadap Pelaksanaan Dasar Tanah Btitish North Borneo Chatered Company (BNBC) di Borneo Utara 1881-1941. Jurnal Kinabalu. Vol. 21, 2015. Hlm. 85.

Mohd Jamil Al-Sufri. (1995). Ringkasan Sejarah Brunei. Jurnal Darussalam. Bil.2. Kementerian Kebudayaan Belia dan Sukan: Brunei Darussalam.

Mohd. Jamil Al-Sufri. (2001). Tarsilah Sultan-Sultan Brunei Sejarah Awal dan Perkembangan Islam. Bandar Seri Begawan: Pusat Sejarah Brunei Kementerian Kebudayaan Belia dan Sukan.

Mohd. Jamil Al-Sufri. (2002). Tarsilah Brunei II, Zaman Kegemilangan dan Kemasyuran. Bandar Seri Begawan: Pusat Sejarah Brunei.

Mohd. Nor Bin Long. (1978). Perkembangan Pelajaran di Sabah. Kuala Lumpur: Dewan Bahasa dan Pustaka.

Nicholl, R. (1990). European Sources For The History of the Sultanate Of Brunei in the Sixteenth Century. Bandar Seri Begawan: Muzium Brunei.

Osman Bin Tahir. (1996/97). Suku Kaum Brunei Sabah; Tumpuan Khusus di Daerah Membakut, Daerah Papar, Bongawan (1860-an Sehingga 1990-an). Tesis Jabatan Sejarah, Fakulti Sastera \& Sains Sosial: Universiti Malaya.

Pengiran Abdul Rahman Bin Pengiran Haji Kassim. (2016). 55 Tahun. Kampung Benoni, Papar. Temubual 24 Disember 2016.

Pengiran Ahmad Fauzi Bin Pengiran Abdul Rahim. (2011). 74 Tahun. Kampung Takis, Papar. Temubual 5 April 2011.

Pengiran Yassin Bin Pengiran Alli (2011). 71 Tahun. Bongawan. Temubual 5 April 2011.

S. Sidhu, Jatswan. (1995). Sejarah SosioEkonomi Brunei 1906-1959. Selangor: Sasyaz Holdings Sdn.Bhd.

Sabihah Osman, Muhammad Hadi Abdullah \& Sabullah Hakip. (2001). Sejarah Brunei Menjelang Kemerdekaan. Kuala Lumpur: Dewan Bahasa dan Pustaka.

Sabihah Osman. (1981). The Development of Native Education In Sabah 1881-1941 'Seminar Sejarah dan Masyarakat Sabah. Kota Kinabalu: Yayasan Sabah.

Saunders , G. (1994). A History of Brunei. United States of America: New York.

Singh, D.S.R. (1991). Brunei 1839-1983; The Problems of Political the Survival. Oxford University: Singapore.

Singh, D.S.R. (2003). The Making Of Sabah 1865-1941 the Dynamics of Indigenous Society. Kuala Lumpur: Universiti Malaya. 
Siti Aidah Hj. Lokin. (2007). Perubahan Sosioekonomi dan Pentadbiran Masyarakat Peribumi Sabah (1881-1963). Kota Kinabalu: Universiti Malaysia Sabah.

Spencer, St.John. (1974). Life in the forests of the far east, vol I, Singapore: Oxford Unversity Press. St.John .S. (1974). Life in the forests of the far east, vol I, Singapore: Oxford Unversity Press.

Sweeney, P.L.A. (1968). Silsilah Raja-Raja Berunai. JMBRAS. Vol. XLI, Pt.2. hlm. 1-82.

Tajuddin Bin Haji Matussin. (2011). 66 Tahun. Kampung Kelanahan, Papar. Temubual 5 April 2011. Tarling, N. (1971). Britain, The Brookes \& Brunei. Kuala Lumpur: Oxford University Press.

Tregonning, K.G. (2007). Under Chartered Company Rule: North Borneo (1881-1946). Kuala Lumpur: University Of Malaya.

Whelan, F. G. (1968). A History of Sabah. Singapore: Heinemann Educational Books.

Wong, D.T.K. (2012). The Papar Land Protest 1910-1911. Journal of Southeast Asian Studies. Vol. 43. Issues 03. hlm. 422-440.

Zaini Bin Haji Ahmad. (1983). Pertumbuhan Nasionalisme di Brunei (1939-1962). Kuala Lumpur: ZR Publication. 